Published as: Oliver, J.J. (2019). Culture also eats innovation for breakfast! Strategic Direction, Vol. 35 No. 12 , pp. 1-3.

\title{
Culture also eats innovation for breakfast!
}

The renowned management consultant, Peter Drucker, is known for (allegedly) saying that 'culture eats strategy for breakfast'. The thrust of his argument was that a firm's corporate culture will have the greatest influence on whether a strategy is successful or not. This paper extends Ducker's line of thinking to consider the lasting effects of a corporate crisis and subsequent adaptive changes in firm culture and performance. This idea is illustrated using UK bank Barclays Plc (Barclays) and examines how its focus on transformative cultural change has resulted in significant adjustments in their attitude to risk and innovation.

\section{A corporate crisis shines a light on a flawed culture}

"If you aint cheating, you aint trying" commented a Barclays Vice-President in 2010. Two years later, on June $27^{\text {th }} 2012$, Barclays was handed the largest fine in UK banking history for their fraudulent and anticompetitive behavior. Barclays were found guilty of manipulating UK (LIBOR) and European (EURIBOR) benchmark interest rates which were used to calculate trillions of dollars worth of financial contracts and derivatives between 2005-09. The fraud boosted their profits and gave the impression to stakeholders and the media that the firm had ridden out the severe effects of the Global Financial Crisis. The outcomes of its behavior resulted in the firm being fined $£ 284.4 \mathrm{~m}$ as part of a $£ 3.9 \mathrm{bn}$ settlement with UK and US regulators who found that they had conspired with the Royal Bank of Scotland, JP Morgan, UBS, Citigroup and Bank of America. Barclay's CEO, Bob Diamond, resigned following the scandal and a downward spiral in corporate financial performance. Indeed, the ramifications of this case continued into 2016, with the firm being fined a further $\$ 100 \mathrm{~m}$ to settle with 44 US states where government and not-for profit agencies had suffered financial losses as a result of the fraud.

This type of corporate behavior gives rise to many questions, but most importantly about the culture that existed at Barclays at the time. In the aftermath of the Global Financial Crisis of 2007-09, a KPMG report (2009) found that many financial firms' corporate culture was dominated by excessive risk taking, stimulated by short term incentive and remuneration policies. As such, Barclays were not an exceptional case when it came to the issue of corporate greed and deception.

\section{Barclays Plc: Aiming for a transformative change in culture}

The Global Financial Crisis highlighted a Barclays corporate culture dominated by excessive risk taking. In the wake of their corporate culpability and fines, the firm introduced new governance structures during 2013, including a Board Conduct, Reputation and Operational Risk Committee and a mandatory training programme for all staff which sought to embed new 'Purpose and Values' throughout the organization and an annually assessed Code of Conduct. Barclays aimed to change their culture and embed a new set of conduct and citizenship values in an attempt to guide it through a transformative phase of organisational development.

Whilst many management scholars and consultants agree that culture is difficult to measure, Barclays have produced a subsequent adaptive change in firm culture that can be quantified. A longitudinal frequency analysis (2000-2017) of a range of 'risk' and 'innovation' words contained in Barclays Annual Reports suggests that its recent focus on changing the culture away from excessive risk taking, may have had a detrimental effect on the level of innovation in the firm. Whilst annual reports are often associated with an inherent bias which presents a firm in the best light possible, they do provide a fertile ground to examine embedded cultural 
Published as: Oliver, J.J. (2019). Culture also eats innovation for breakfast! Strategic Direction, Vol. 35 No. 12, pp. 1-3.

values and beliefs, whilst also meeting the demands of investors, stakeholders and regulatory bodies.

The word frequency analysis shows that during and post the Global Financial Crisis, the number of risk related words that Barclays used increased dramatically (see Figure 1). These remained at higher levels in the wake of their 2012 crisis because of a subsequent adaptive cultural change that placed an increased emphasis on risk aversion, personal conduct and citizenship values. On the other hand, the number of innovation related words has more or less remained steady for nearly 20 years. This suggests that Barclays is not creating a culture which cultivates innovation, indeed, the word 'creativity' was has only been used four times in 18 years and not once since its crisis event in 2012. This may go some way to explaining their poor financial performance since a comparison of their Operating Income and EBIT in the 6 years before the crisis, and the 6 years post this event, indicate decreases of $36 \%$ and $76 \%$ respectively. Whilst Barclays have quite rightly placed cultural change at the centre of their transformative process, its increased emphasis on risk aversion may be to the detriment of the types of innovative attitudes and behaviors that drive improved revenues and earnings.

Figure 1: Risk and Innovation Word Frequency Analysis (2000-2017)

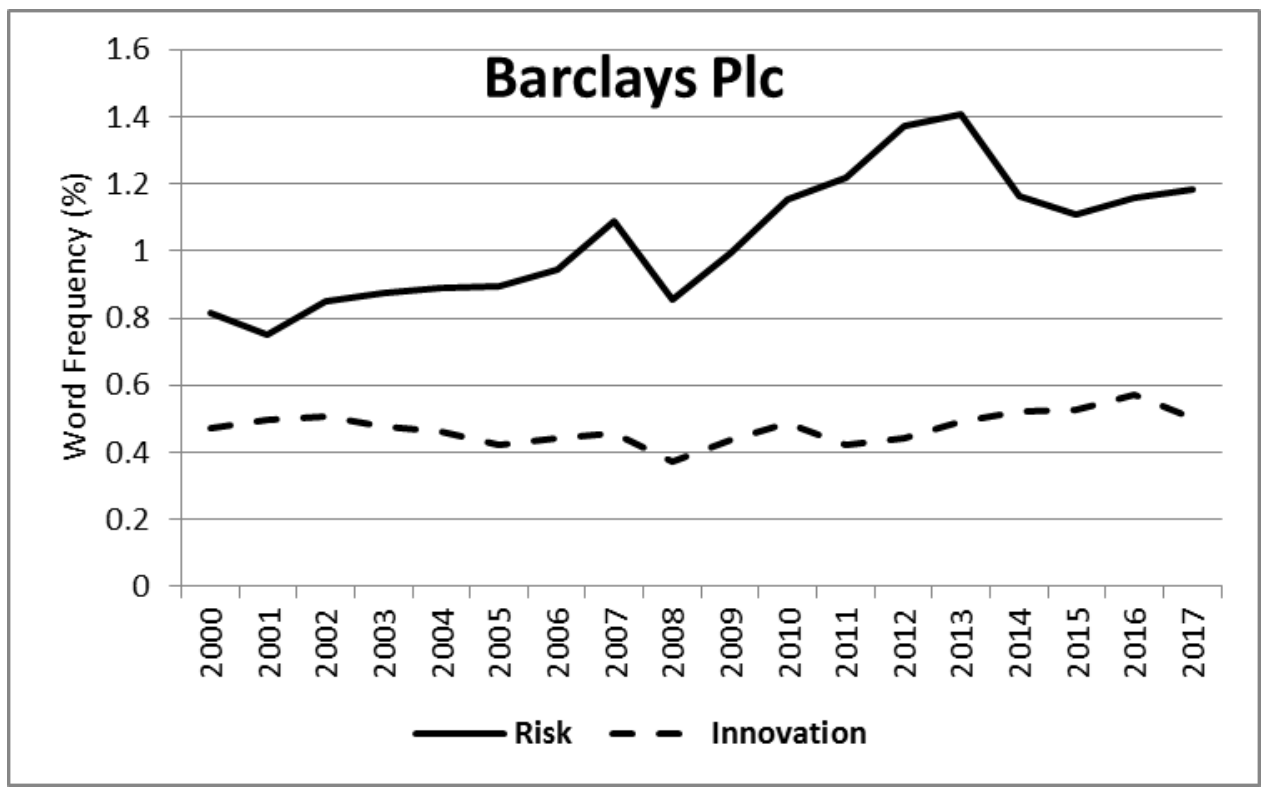

Souce: Barclays Plc Annual Reports (2000-2017)

\section{Conclusion}

Drucker was right... and then some. Whilst many management consultants agree that the success of a new strategy is heavily dependent on the culture that exists in a firm, it also plays an import role in shaping every aspect firm performance. Corporate crisis events, like the penalty imposed on Barclays for fraudulent and anticompetitive behavior, have the ability to create adaptive responses in firm culture. As we have seen in the analysis above, these responses can have lasting effects well beyond their immediate impact, and in Barclay's case, a reduced level of innovation in favour of risk aversion which may be inhibiting their financial performance. 
Published as: Oliver, J.J. (2019). Culture also eats innovation for breakfast! Strategic Direction, Vol. 35 No. 12, pp. 1-3.

\section{Note}

1. The New York State Department of Financial Services, Barclays Bank Plc, Consent Order, page 14. (available at: www.dfs.ny.gov/system/files/documents/2019/01/ea181218_barclays. pdf (accessed 5 September 2019).

\section{References}

Coffman, C., \& Sorensen, K. (2013), "Culture Eats Strategy for Lunch: The Secret of Extraordinary Results, Igniting the Passion Within”, BookBaby.

KPMG (2009), "Never Again? Risk Management in Banking beyond the Credit Crisis".

\section{Corresponding author}

John J. Oliver can be contacted at: joliver@bournemouth.ac.uk 